\title{
Clinical Applications of Circulating Tumor Cells in Pharmacotherapy: Challenges and Perspectives
}

\author{
Tong Wu, Bin Cheng, and Liwu Fu \\ State Key Laboratory of Oncology in South China, Collaborative Innovation Center for Cancer Medicine, Guangdong Esophageal \\ Cancer Institute (T.W., L.F.); and Department of Oral Medicine, Guanghua School of Stomatology, Guangdong Provincial Key \\ Laboratory of Stomatology, Sun Yat-sen University, Guangzhou, China (T.W., B.C.)
}

Received December 31, 2016; accepted March 22, 2017

\section{ABSTRACT}

Screening for circulating tumor cells (CTCs) has been identified as one approach to ultrasensitive liquid biopsy in real-time monitoring of cancer patients. The detection of CTCs in peripheral blood from cancer patients is promising as a diagnostic tool; however, the application of CTCs in therapeutic treatment still faces serious challenges with respect to specificity and sensitivity. Here, we review the significant roles of CTCs in metastasis and the strengths and weaknesses of the currently available methods for CTC detection and characterization. Moreover, we discuss the clinical application of CTCs as markers for patient prognosis, and we specifically focus on the application of CTCs as indicators in cancer pharmacotherapy. Characterization of the detected CTCs will provide new biologic perspectives and clinical applications for the treatment of cancer patients with metastasis.

\section{Introduction}

A fraction of the cancer cells that disseminate from primary tumors and migrate to distant sites will result in the formation of a lethal metastatic tumor (Hanahan and Weinberg, 2011). Migrating tumor cells found in the peripheral bloodstream are called circulating tumor cells (CTCs), while their counterparts found in bone marrow are called disseminated tumor cells (Alix-Panabieres and Pantel, 2016). CTCs have been regarded as a critical stage in the development of metastasis, in that they contain genetic and molecular information about the cancer as well as its evolutionary adaptation to prior therapies (Alix-Panabières and Pantel, 2016). However, CTCs have also been detected in the blood circulation of healthy volunteers, and in patients with benign diseases of the lung, colon, pancreas, and breast (Franken et al., 2012; Pantel et al., 2012; Ilie et al., 2014; Markou et al., 2014; Alva et al., 2015; Cauley et al., 2015; Liu et al., 2015).

CTCs have paved new diagnostic avenues in liquid biopsy diagnostics, especially for tumors that are not easy to biopsy

This work was supported by the National Nature Scientific Foundation [Grants 81473233 and 81600878], International Collaboration Science Research Foundation of Guangdong Province [Grant 2013B051000046], Medical Science and Technology Research Fund of Guangdong Province [Grant B2013145], Natural Science Foundation of Guangdong Province [Grant 2016A030310217], and Medical Scientific Research Foundation of Guangdong Province [Grant A2016096].

https://doi.org/10.1124/mol.116.108142. and for metastatic lesions (Azarin et al., 2015). Early detection of cancer metastasis is always difficult, not to mention its prevention or cure. With its noninvasive nature and real-time advantage, cancer screening for CTCs can be applied to populations at higher risk. Therefore, oncologists place high hopes on CTC-based screening methods, which have been found to be more sensitive than current imaging methods such as positron emission tomography (Hegemann et al., 2016). The consistency between CTCs and their primary tumors is encouraging, and may provide an excellent opportunity for clinicians to examine mutations of key genes that are not detected through traditional blood-based assays (Nagrath et al., 2016). In the era of precision medicine in cancer therapy, systemic monitoring of response to anticancer therapies is a key step toward providing personalized care. An increasing body of evidence indicates that, in the course of treatment, assessment of the molecular characteristics of a progressive disease is more significant than depending on the results obtained for primary tumor samples, which do not reflect the evolution of the tumor (Alix-Panabières and Pantel, 2016). Comprehensive information regarding whole disease processes obtained from studies on CTCs has not only revealed the underlying mechanisms of tumorigenesis and metastasis, but has also provided noninvasive methods for cancer diagnosis, prognosis, and pharmacotherapy monitoring (Masuda et al., 2016).

Recent research has demonstrated that CTCs, an integral part of the liquid biopsy, have great potential to change the

ABBREVIATIONS: AR-V7, androgen receptor splice variant 7; CK, cytokeratins; CTC, circulating tumor cell; EGFR, epidermal growth factor receptor; EMT, epithelial-to-mesenchymal transition. 
status quo of anticancer therapy; however, the approach remains technically challenging. Following a short discussion of the significant roles of CTCs in cancer metastasis and the currently available methods for CTC detection and molecular characterization, this review will focus on the clinical applications of CTCs as markers for prognosis prediction in cancer patients and as indicators in cancer pharmacotherapy (Fig. 1).

\section{CTCs and Cancer Metastasis}

The malignant form of cancer and the cause of more than $90 \%$ of cancer-associated mortality cases is metastasis, which is characterized by the ability of cancer cells to invade the surrounding tissue, disseminate throughout the body, and establish secondary tumors in distant organs (Gupta and Massagué, 2006). As shown in Fig. 2, the sequential metastasis process is first initiated by the loss of adhesion of tumor cells in the primary site and their migration out of the primary tumor. Second, the tumor cells attach to blood vessels and invade the blood or lymphatic circulation in a process called intravasation (Fidler, 2003). As the tumor cells circulate to the secondary site, the tumor cells intrude blood vessels, adhere to the target organ endothelium, and migrate into the parenchyma; this is called extravasation (Klein, 2009; Chaffer and Weinberg, 2011; Sosa et al., 2014). Therefore, the existence of CTCs has been recognized as an important intermediate step in cancer metastasis. CTCs represent a stem-like subpopulation of cells that are capable of immigration and tumor initiation (Al-Hajj et al., 2003; Ricci-Vitiani et al., 2007; Stewart et al., 2011). During the metastasis process, many cell surface markers of CTCs undergo change. The activation of an epithelial-to-mesenchymal transition (EMT) facilitates tumor cell invasion and dissemination during intravasation, while its reverse process, a mesenchymal-to-epithelial transition, is believed to support extravasation once cancer cells have arrived in distant organs (Acloque et al., 2009; Thiery et al., 2009; Nieto, 2013). It has been speculated that the entire process in which CTCs seed metastasis occurs with extremely low efficiency; only $0.01 \%$ of all CTCs can survive and form micrometastases in distant organs (Luzzi et al., 1998). Even if CTCs succeed in intravasation, most of them cannot survive the adverse environment in the bloodstream and eventually die from anoikis. Therefore, CTCs sometimes aggregate to form microemboli (circulating tumor microemboli), which may be advantageous in the survival of tumor cells and enhance the viability and motility of CTCs (Krebs et al., 2014).

For several decades, the lack of relevant models for metastasis research has extensively limited further investigation. CTCs are the true link between primary and metastatic tumors, and thus create a new opportunity for investigators to explore valuable features of both primary and metastatic sites, as well as specific details of the processes of intravasation, migration, and extravasation.

\section{CTC Detection}

As previously mentioned, after CTCs are released from the main and/or metastatic tumor site into the blood circulation, the conditions in the blood are harsh for epithelial tumor cells, and the survival time of CTCs is extremely short (half-life: 12.4 hours) (Meng et al., 2004). Apoptotic and fragmented CTCs are frequently detected in the peripheral bloodstream of cancer patients (Larson et al., 2004). Therefore, a pivotal challenge in the clinical application of CTCs is the capability of the current CTC technology to efficiently capture the extremely rare CTC population from blood samples of patients for subsequent processing (Nelson, 2010).

In the past decade, one of the most widely used strategies to detect CTCs has been the use of epithelial markers such as cytokeratins (CKs) and EpCAM, which are not detected in the surrounding mesenchymal blood cells. CellSearch, the only U.S. Food and Drug Administration approved CTC technology to monitor metastatic breast cancer patients, is a case in point (Ferreira et al., 2016). The CellSearch system uses ferrofluid functionalized nanoparticles containing the EpCAM antibody for magnetic separation of EpCAM positive cells after blood centrifugation for the enrichment of CTCs. The cells are then selected by immunostaining for the expression of CK8, CK18, and CK19, as well as for negative staining for CD45 (Riethdorf et al., 2007).

However, further research has demonstrated that epithelial tumor cells are likely to undergo EMT, which results in

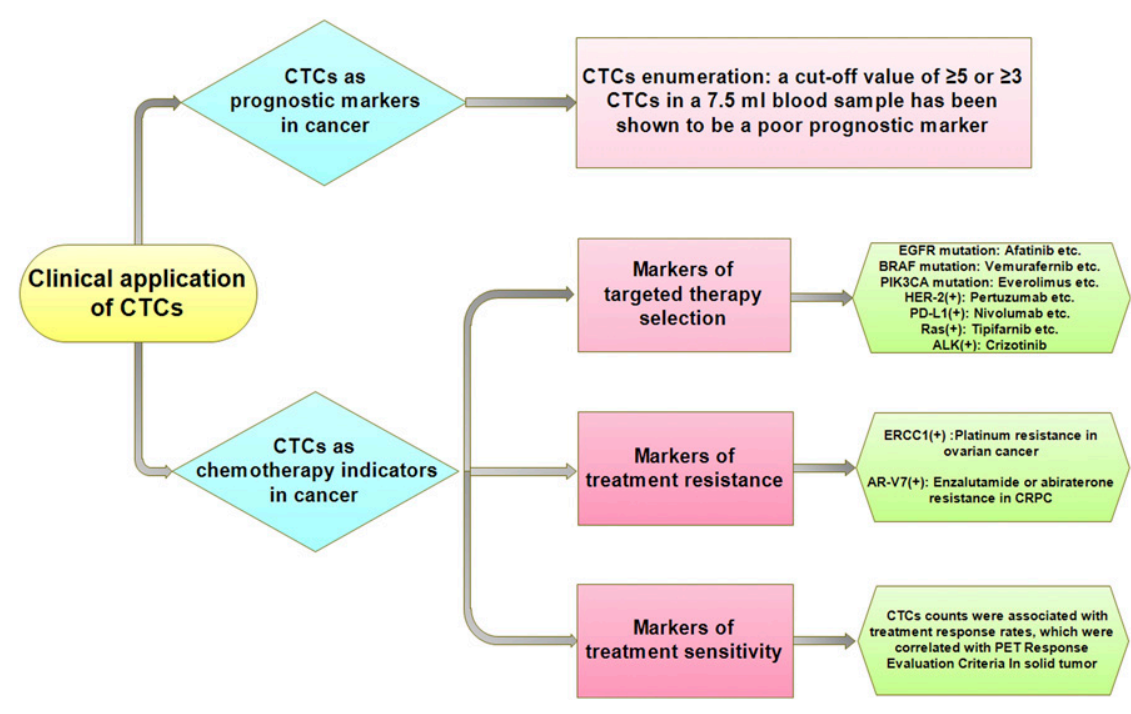

Fig. 1. Clinical application of CTCs as liquid biopsy. Recent research has demonstrated that CTCs, an integral part of the liquid biopsy, have great potential to change the status quo of cancer therapy. One of the most commonly used clinical applications of CTCs is as markers for cancer patient prognosis prediction based on CTC enumeration. Other categories of CTC clinical application are as indicators in cancer pharmacotherapy such as markers of targeted therapy selection, treatment resistance, and sensitivity. 


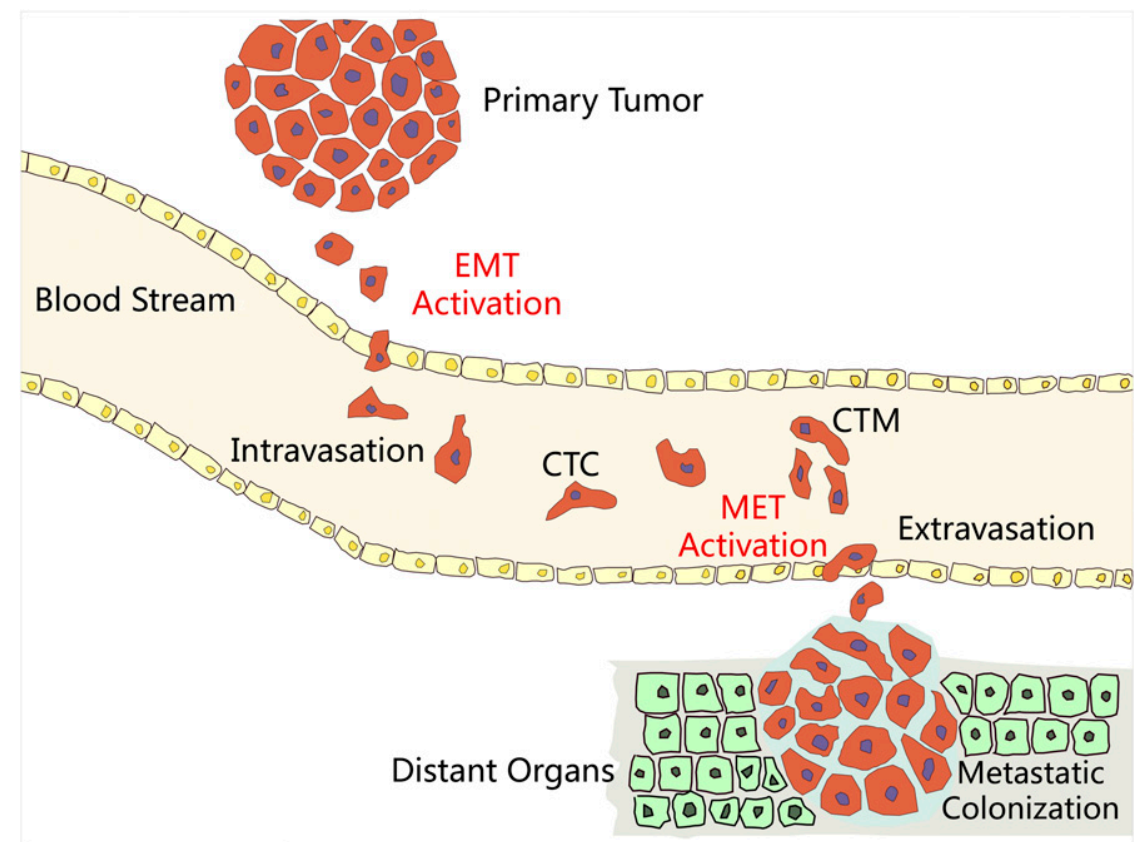

Fig. 2. Schematic representation of the participation of CTCs in multiple stages of metastasis. The sequential metastasis process initiates with a loss of adhesion of tumor cells in the primary site and their migration out of the primary tumor. Next, the tumor cells attach to the blood vessels and invade the blood or lymphatic circulation, which is called intravasation. The activation of EMT facilitates tumor cell invasion and dissemination during intravasation. CTCs sometimes aggregate to form microemboli [circulating tumor microemboli (CTM)], which may endow tumor cells with advantages in survival and enhances their viability and motility. As the tumor cells circulate to the secondary site, they intrude blood vessels and adhere to the target organ endothelium and migrate into the parenchyma, which is called extravasation. Activation of mesenchymal-to-epithelial transition (MET) is believed to support this extravasation once cancer cells have arrived in distant organs.

decreased expression of epithelial markers and increased plasticity, migration, and invasiveness (Mani et al., 2008). These partial EMT tumor cells, also called the intermediate phenotype, have the highest versatility and are able to adapt to the microenvironment in secondary sites (Tam and Weinberg, 2013). Therefore, in recent years a variety of devices have been developed for the enrichment and detection of CTCs undergoing EMT, in addition to the approaches that select epithelial markers (Alix-Panabières and Pantel, 2014). CTC assays usually involve two steps. First, an enrichment step increases the percentage of CTCs, making it easier to detect single tumor cells. Specifically, CTCs can be enriched by their biologic characteristics (e.g., protein markers) or on the basis of their physical properties (e.g., size, density, deformability, or electric charges). Second, in the detection step, CTCs can be selected using different criteria such as immunologic, molecular, or functional assays (Table 1) (Ferreira et al., 2016). To date, although CTC technologies have developed rapidly, sensitivity and specificity are still problems that hinder the clinical utilization of CTCs in guiding the personalized treatment of cancer patients (Hardingham et al., 2015).

\section{CTCs as Prognostic Markers in Cancer}

Currently, CTC enumeration is widely used as a prognostic index for patient overall survival rate. A cutoff value of $\geq 5$ or $\geq 3 \mathrm{CTCs}$ in $7.5 \mathrm{ml}$ blood has been proven to be a poor prognostic index in several cancers, including breast cancer (Zhang et al., 2012), colorectal cancer (Cohen et al., 2008), prostate cancer (de Bono et al., 2008), lung cancer (Krebs et al., 2011), bladder cancer (Gazzaniga et al., 2014), liver cancer (Schulze et al., 2013), esophageal cancer (Vashist et al., 2012), melanoma (Rao et al., 2011), head and neck carcinoma (Nichols et al., 2012), and pancreatic cancer (Han et al., 2014).

The association between detection of CTCs and clinical outcome has been most widely studied in breast cancer. For example, CTCs were analyzed in a pool of 2026 patients with early stage breast cancer before pharmacotherapy and 1492 patients after pharmacotherapy using the CellSearch System (Rack et al., 2014). In the pre-pharmacotherapy group, CTCs were found in $21.5 \%$ of patients, in which $19.6 \%$ were lymph node negative and $22.4 \%$ were node positive. No correlation was found between CTCs and tumor size, grading, or hormone receptor status. CTCs were detected in $22.1 \%$ of 1492 patients after chemotherapy. The presence of CTCs was associated with poor rates of diseasefree, distant disease-free, breast cancer-specific, and overall survival. CTCs were identified as an independent prognostic index for disease-free survival in multivariable analysis. Patients with more than five CTCs per $30 \mathrm{ml}$ blood had the worst prognosis. These results from a large-scale trial of patients with breast cancer suggested that CTCs have prognostic value (Rack et al., 2014).

Of note, in these reports indicating that CTCs can be used as a reliable early index of disease progression and survival compared with traditional methods, a significant proportion of patients with obvious distant metastases were negative for CTCs. This result implied that CTCs undergoing EMT transformation can be missed by epithelial marker-based detection methods, such as the CellSearch system. Therefore, largescale multicenter trials with improved CTC detection techniques and well-defined endpoints are needed to support the clinical utility of CTC detection in cancer patients.

\section{CTCs as Indicators in Pharmacotherapy}

CTCs may be disseminated from the primary tumor or from a number of metastatic sites. Therefore, CTCs offer a wealth of genetic and molecular information concerning the cancer at the protein, RNA, and genome levels (Meng et al., 2004). In addition to CTC detection, significant effort has been made toward CTC characterization. In the era of precision medicine of cancer therapy, identification of CTCs expressing certain markers can be used to specifically monitor cancer therapy. 


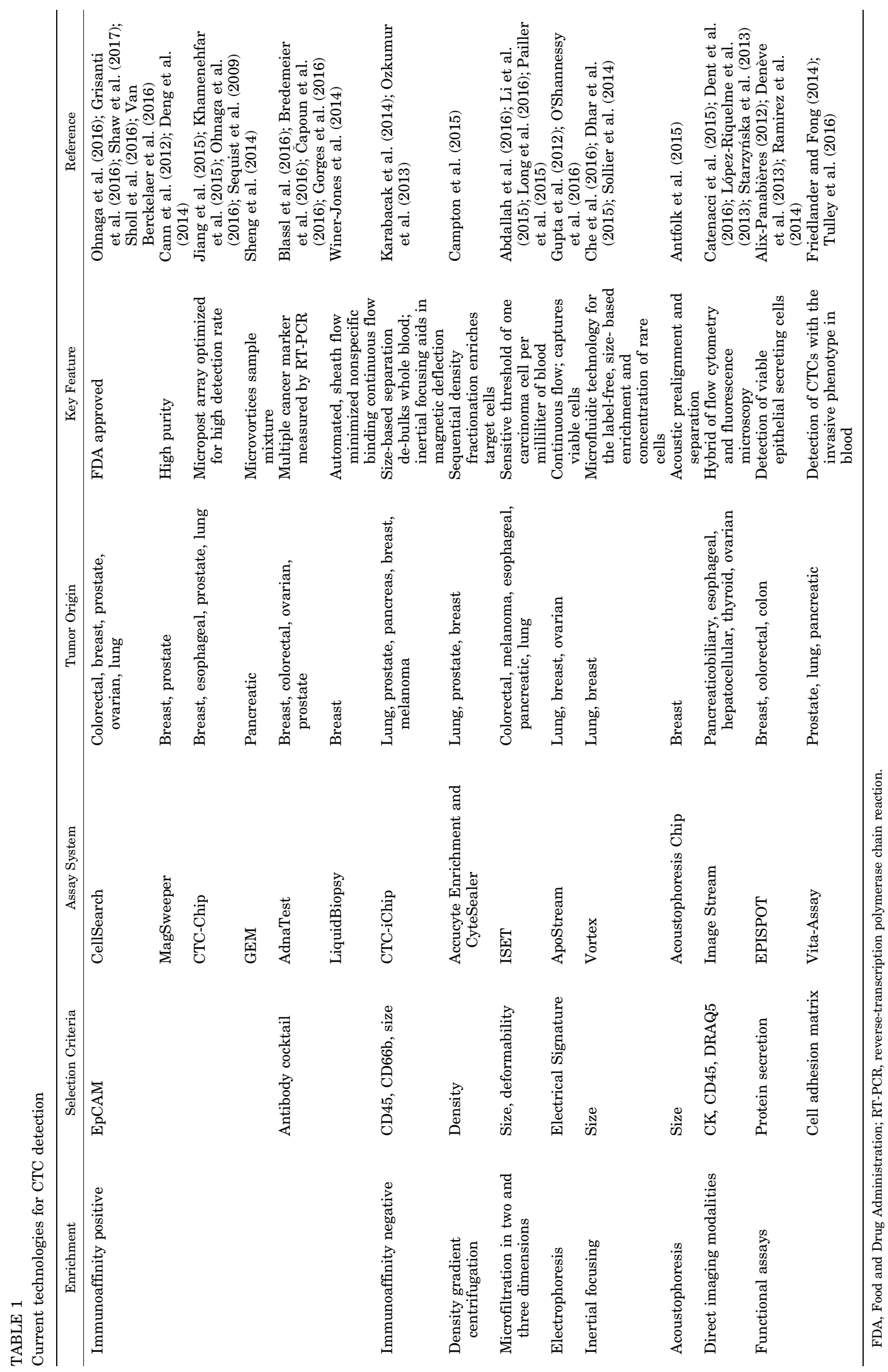

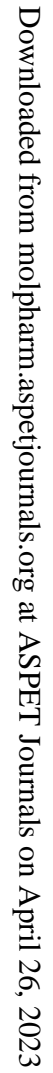


CTCs as Markers for Targeted Therapy Selection. Molecular alterations in CTCs have proven to be highly consistent in primary tumors, thus providing robust evidence for the clinical application of targeted therapies in cancer. Several studies have suggested that CTCs can be used as an index in therapy selection, and that they can also be used in real-time biopsies to reflect the effect of a particular therapy.

For example, BRAF mutations between primary tumors and metastases have been found in patients; these mutations mediate tumor proliferation through activation of the RAFMEK-ERK pathway (Lin et al., 2011). Therefore, the BRAF mutation status in CTCs collected from patients with metastatic melanoma is a pivotal index in selecting targeted therapies such as vemurafenib and dabrafenib (Jang and Atkins, 2014; Reid et al., 2015). Another case in point is epidermal growth factor receptor (EGFR) mutations in lung cancer. A group of pulmonary adenocarcinoma that has activating EGFR mutations is exclusively sensitive to EGFR tyrosine kinase inhibitors (Mok et al., 2009). Therefore, EGFR mutations in CTCs are clinical biomarkers in the categorization of pharmacotherapy targets in metastatic lung cancer with respect to treatment with erlotinib, afatinib, and osimertinib (Breitenbuecher et al., 2014; Kuwano et al., 2016). In addition to melanoma and lung cancer, therapeutic targets were identified in breast cancer. The phosphatidylinositide 3-kinase/protein kinase $\mathrm{B} / \mathrm{mammalian}$ target of the rapamycin pathway is frequently altered in cancer. Phosphatidylinositide 3-kinase is a cell membrane signal transduction molecule that supports cell survival and growth, making it a popular therapeutic target (Wong et al., 2010; Akinleye et al., 2013). PIK3CA mutations were identified in CTCs from metastasis breast cancer patients by CellSearch enrichment, DNA extraction, and whole genome amplification (Schneck et al., 2013); therefore, agents that target this pathway, such as everolimus and temsirolimus, are promising therapeutic options (Johnston, 2015).

Another application of CTCs is in the detection of various biomarkers expressed in advanced disease that reflect the progression of the cancer. The hormone receptor status is one of the most well-established predictors in endocrine adjuvant or palliative therapy of primary and metastatic breast cancer. However, the hormone receptor status changes during the course of disease progression. Variations in the expression of estrogen receptor and human epidermal growth factor receptor 2 can occur in advanced breast cancer, and has been readily detected in CTCs. Monitoring these changes is helpful when selecting chemotherapies, especially those targeting the human epidermal growth factor receptor, such as trastuzumab, lapatinib, pertuzumab, and trastuzumab-emtansine (Thompson et al., 2010; Aktas et al., 2011; Turner and Di Leo, 2013; Hernández-Blanquisett et al., 2016) . In addition, several therapeutic targets such as anaplastic lymphoma kinase (Ilie et al., 2012; Pailler et al., 2013), PD-L1 (Jing et al., 2016), and RAS (Karandish and Mallik, 2016), were also detected in CTCs collected from breast, colorectal, prostate, and ovarian cancer patients (Fig. 3).

CTCs as Markers of Treatment Resistance. It has been reported that in both early and metastatic cancers the presence of CTCs following treatment can act as a predictive index of the possibility of disease recurrence (Xenidis et al., 2007; Alix-Panabières and Pantel, 2013). These persisting CTCs are resistant to treatment and can thus be involved in cancer progression. Therefore, there is an urgent need to identify effective therapies in patients with therapy-resistant CTCs. Several studies have been reported based on this strategy. For example, platinum resistance is one of the most recognized clinical challenges for ovarian cancer pharmacotherapy. While detection of the ERCC1 protein in the primary tumor by immunohistochemistry is inaccurate in predicting platinum resistance, the presence of $\mathrm{ERCC} 1^{+}$CTCs in blood can be used as a diagnostic biomarker in ovarian cancer to predict platinum resistance (Kuhlmann et al., 2014). In metastatic castration-resistant prostate cancer, the presence of androgen receptor splice variant 7 (AR-V7) in CTCs is associated with resistance to enzalutamide and abiraterone, but not to taxanes (Antonarakis et al., 2014, 2015). In AR-V7positive patients, taxanes are more efficacious than enzalutamide or abiraterone therapy in AR-V7-positive tumors, while in AR-V7-negative patients, taxanes, enzalutamide, and abiraterone have quite similar efficacies (Antonarakis et al., 2015). Therefore, AR-V7 expressed in CTCs may serve as a biomarker for castration-resistant prostate cancer treatment selection (Onstenk et al., 2015). These results add to existing evidence that CTCs are a valuable tool that can be used to optimize personalized cancer treatments and improve the prognosis in therapy-resistant patients.

CTCs as a Biomarker for Treatment Sensitivity. Increasing evidence points to the significance of evaluating the molecular features of advancing disease during therapy instead of depending on primary tumor samples, which are unable to reflect the progression of a tumor and target the associated features (Alix-Panabières and Pantel, 2016). Considering the easy availability of blood, it has been suggested that CTCs can serve as a real-time liquid biopsy to provide information on a current disease without invasive biopsy (Lianidou and Markou, 2011).

CTC enumeration is one of the most widely used criteria to monitor systemic anticancer therapy. The significance of CTC enumeration in monitoring anticancer therapy has been demonstrated in metastatic breast cancer patients receiving

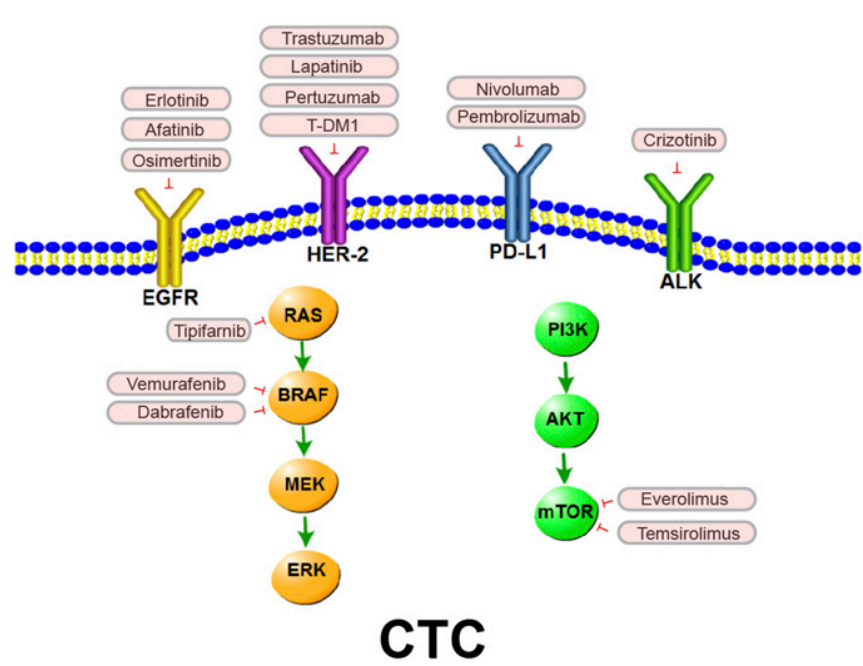

Fig. 3. Chemotherapeutic targets identified in CTCs and their representative target agents. Several therapeutic targets such as EGFR, human epidermal growth factor receptor 2 (HER-2), anaplastic lymphoma kinase (ALK), PD-L1, and RAS were detected in CTCs collected from lung, breast, colorectal, prostate, and ovarian cancer. These proteins are clinical biomarkers for target therapy selection. 
first-line chemotherapy. In the SWOG 0500 (NCT00382018) clinical trial (http://swog.org/visitors/ViewProtocolDetails.asp? ProtocolID=2046), patients with metastatic breast cancer had CTC enumeration before cycles 1 and 2 with or without targeted therapy in combination with first-line chemotherapy. Patients with sustained increases in the CTC number $(\geq 5 \mathrm{CTCs} / 7.5 \mathrm{ml})$ after one cycle of treatment were regarded as a higher risk group for early cancer progression. These patients were randomly designated into a continued first-line pharmacotherapy group or another treatment group before radiologic evaluation of progression (Bidard et al., 2016). For patients with continued increases in CTC numbers after first-line chemotherapy, a more effective treatment than standard chemotherapy is needed (Smerage et al., 2014). Several multicenter clinical trials testing anticancer therapy monitoring based on CTCs are still in progress, including the STIC CTC METABREAST clinical trial in France (NCT01710605) (https://clinicaltrials.gov/ct2/show/NCT01710605). In this trial, breast cancer patients with more than five CTC counts in $7.5 \mathrm{ml}$ blood received chemotherapy, while patients with no more than five CTCs in $7.5 \mathrm{ml}$ blood received endocrine therapy as the first-line treatment (Lianidou and Markou, 2011). In a phase II trial of erlotinib and pertuzumab in advanced nonsmall cell lung cancer, CTC counts were associated with treatment response rates, which were correlated with fludeoxyglucose positron emission tomography (Punnoose et al., 2012).

\section{Future Prospects and Challenges}

There is no doubt that innovative approaches utilizing CTCs have paved new diagnostic avenues for the next generation of liquid biopsy diagnostics, especially in tumors that are not easy to biopsy and in metastatic lesions. Furthermore, based on their noninvasive and real-time advantages, CTCs can be applied in cancer screening of populations at higher risk. Identification and characterization of CTCs have been applied in several key clinical areas, such as prognosis prediction, systemic pharmacotherapy selection, and monitoring. However, although some promising results have been reported, detection of CTCs still faces serious challenges, including sensitivity and specificity. In the future, more efficient capture systems and larger panels of detection markers will be explored to avoid losing assay specificity while increasing sensitivity. In conclusion, the detection and characterization of CTCs will provide new biologic perspectives and clinical implications for cancer patients, especially during pharmacotherapy.

\section{Authorship Contributions}

Wrote or contributed to the writing of manuscript: $\mathrm{Wu}, \mathrm{Cheng}, \mathrm{Fu}$.

\section{References}

Abdallah EA, Fanelli MF, Souza E Silva V, Machado Netto MC, Gasparini Junior JL, Araújo DV, Ocea LM, Buim ME, Tariki MS, Alves VdaS, et al. (2016) MRP1 expression in CTCs confers resistance to irinotecan-based chemotherapy in metastatic colorectal cancer. Int J Cancer 139:890-898.

Acloque H, Adams MS, Fishwick K, Bronner-Fraser M, and Nieto MA (2009) Epithelial-mesenchymal transitions: the importance of changing cell state in development and disease. J Clin Invest 119:1438-1449.

Akinleye A, Avvaru P, Furqan M, Song Y, and Liu D (2013) Phosphatidylinositol 3-kinase (PI3K) inhibitors as cancer therapeutics. J Hematol Oncol 6:88.

Aktas B, Müller V, Tewes M, Zeitz J, Kasimir-Bauer S, Loehberg CR, Rack B, Schneeweiss A, and Fehm T (2011) Comparison of estrogen and progesterone receptor status of circulating tumor cells and the primary tumor in metastatic breast cancer patients. Gynecol Oncol 122:356-360.
Al-Hajj M, Wicha MS, Benito-Hernandez A, Morrison SJ, and Clarke MF (2003) Prospective identification of tumorigenic breast cancer cells. Proc Natl Acad Sci USA 100:3983-3988.

Alix-Panabières C (2012) EPISPOT assay: detection of viable DTCs/CTCs in solid tumor patients. Recent Results Cancer Res 195:69-76

Alix-Panabières C and Pantel K (2013) Circulating tumor cells: liquid biopsy of cancer. Clin Chem 59:110-118.

Alix-Panabières C and Pantel K (2014) Challenges in circulating tumour cell research. Nat Rev Cancer 14:623-631.

Alix-Panabières C and Pantel K (2016) Clinical applications of circulating tumor cells and circulating tumor DNA as liquid biopsy. Cancer Discov 6:479-491.

Alva A, Friedlander T, Clark M, Huebner T, Daignault S, Hussain M, Lee C, Hafez K, Hollenbeck B, Weizer A, et al. (2015) Circulating tumor cells as potential biomarkers in bladder cancer. J Urol 194:790-798.

Antfolk M, Magnusson C, Augustsson P, Lilja H, and Laurell T (2015) Acoustofluidic, label-free separation and simultaneous concentration of rare tumor cells from white blood cells. Anal Chem 87:9322-9328.

Antonarakis ES, Lu C, Luber B, Wang H, Chen Y, Nakazawa M, Nadal R, Paller CJ, Denmeade SR, Carducci MA, et al. (2015) Androgen receptor splice variant 7 and efficacy of taxane chemotherapy in patients with metastatic castration-resistant prostate cancer. JAMA Oncol 1:582-591.

Antonarakis ES, Lu C, Wang H, Luber B, Nakazawa M, Roeser JC, Chen Y, Mohammad TA, Chen Y, Fedor HL, et al. (2014) AR-V7 and resistance to enzalutamide and abiraterone in prostate cancer. $N$ Engl J Med 371:1028-1038.

Azarin SM, Yi J, Gower RM, Aguado BA, Sullivan ME, Goodman AG, Jiang EJ, Rao SS, Ren Y, Tucker SL, et al. (2015) In vivo capture and label-free detection of early metastatic cells. Nat Commun 6:8094.

Bidard FC, Proudhon C, and Pierga JY (2016) Circulating tumor cells in breast cancer. Mol Oncol 10:418-430.

Blassl C, Kuhlmann JD, Webers A, Wimberger P, Fehm T, and Neubauer H (2016) Gene expression profiling of single circulating tumor cells in ovarian cancer Establishment of a multi-marker gene panel. Mol Oncol 10:1030-1042.

Bredemeier M, Edimiris P, Tewes M, Mach P, Aktas B, Schellbach D, Wagner J, Kimmig R, and Kasimir-Bauer S (2016) Establishment of a multimarker qPCR panel for the molecular characterization of circulating tumor cells in blood samples of metastatic breast cancer patients during the course of palliative treatment. Oncotarget 7:41677-41690.

Breitenbuecher F, Hoffarth S, Worm K, Cortes-Incio D, Gauler TC, Köhler J, Herold T, Schmid KW, Freitag L, Kasper S, et al. (2014) Development of a highly sensitive and specific method for detection of circulating tumor cells harboring somatic mutations in non-small-cell lung cancer patients. PLoS One 9:e85350.

Campton DE, Ramirez AB, Nordberg JJ, Drovetto N, Clein AC, Varshavskaya P, Friemel BH, Quarre S, Breman A, Dorschner M, et al. (2015) High-recovery visual identification and single-cell retrieval of circulating tumor cells for genomic analysis using a dual-technology platform integrated with automated immunofluorescence staining. BMC Cancer 15:360.

Cann GM, Gulzar ZG, Cooper S, Li R, Luo S, Tat M, Stuart S, Schroth G, Srinivas S, Ronaghi M, et al. (2012) mRNA-Seq of single prostate cancer circulating tumor cells reveals recapitulation of gene expression and pathways found in prostate cancer. PLoS One 7:e49144.

Čapoun O, Mikulová V, Jančíková M, Honová H, Kološtová K, Sobotka R, Michael P, Zima T, Hanuš T, and Soukup V (2016) Prognosis of castration-resistant prostate cancer patients-Use of the AdnaTest ${ }^{\circledR}$ system for detection of circulating tumor cells. Anticancer Res 36:2019-2026.

Catenacci DV, Chapman CG, Xu P, Koons A, Konda VJ, Siddiqui UD, and Waxman I (2015) Acquisition of portal venous circulating tumor cells from patients with pancreaticobiliary cancers by endoscopic ultrasound. Gastroenterology 149: 1794-1803.e4.

Cauley CE, Pitman MB, Zhou J, Perkins J, Kuleman B, Liss AS, Fernandez-Del Castillo C, Warshaw AL, Lillemoe KD, and Thayer SP (2015) Circulating epithelial cells in patients with pancreatic lesions: clinical and pathologic findings. J Am Coll Surg 221:699-707.

Chaffer CL and Weinberg RA (2011) A perspective on cancer cell metastasis. Science 331:1559-1564.

Che J, Yu V, Dhar M, Renier C, Matsumoto M, Heirich K, Garon EB, Goldman J, Rao J, Sledge GW, et al. (2016) Classification of large circulating tumor cells isolated with ultra-high throughput microfluidic Vortex technology. Oncotarget 7: 12748-12760.

Cohen SJ, Punt CJ, Iannotti N, Saidman BH, Sabbath KD, Gabrail NY, Picus J, Morse M, Mitchell E, Miller MC, et al. (2008) Relationship of circulating tumor cells to tumor response, progression-free survival, and overall survival in patients with metastatic colorectal cancer. J Clin Oncol 26:3213-3221.

de Bono JS, Scher HI, Montgomery RB, Parker C, Miller MC, Tissing H, Doyle GV, Terstappen LW, Pienta KJ, and Raghavan D (2008) Circulating tumor cells predict survival benefit from treatment in metastatic castration-resistant prostate cancer. Clin Cancer Res 14:6302-6309.

Denève E, Riethdorf S, Ramos J, Nocca D, Coffy A, Daurès JP, Maudelonde T, Fabre JM, Pantel K, and Alix-Panabières C (2013) Capture of viable circulating tumor cells in the liver of colorectal cancer patients. Clin Chem 59:1384-1392.

Deng Y, Zhang Y, Sun S, Wang Z, Wang M, Yu B, Czajkowsky DM, Liu B, Li Y, Wei $\mathrm{W}$, et al. (2014) An integrated microfluidic chip system for single-cell secretion profiling of rare circulating tumor cells. Sci Rep 4:7499.

Dent BM, Ogle LF, O'Donnell RL, Hayes N, Malik U, Curtin NJ, Boddy AV, Plummer ER, Edmondson RJ, Reeves HL, et al. (2016) High-resolution imaging for the detection and characterisation of circulating tumour cells from patients with oesophageal, hepatocellular, thyroid and ovarian cancers. Int J Cancer 138:206-216.

Dhar M, Wong J, Karimi A, Che J, Renier C, Matsumoto M, Triboulet M, Garon EB, Goldman JW, Rettig MB, et al. (2015) High efficiency vortex trapping of circulating tumor cells. Biomicrofluidics 9:064116. 
Ferreira MM, Ramani VC, and Jeffrey SS (2016) Circulating tumor cell technologies. Mol Oncol 10:374-394.

Fidler IJ (2003) The pathogenesis of cancer metastasis: the 'seed and soil' hypothesis revisited. Nat Rev Cancer 3:453-458.

Franken B, de Groot MR, Mastboom WJ, Vermes I, van der Palen J, Tibbe AG, and Terstappen LW (2012) Circulating tumor cells, disease recurrence and survival in newly diagnosed breast cancer. Breast Cancer Res 14:R133.

Friedlander TW and Fong L (2014) The end of the beginning: circulating tumor cells as a biomarker in castration-resistant prostate cancer. J Clin Oncol 32:1104-1106.

Gazzaniga P, de Berardinis E, Raimondi C, Gradilone A, Busetto GM, De Falco E, Nicolazzo C, Giovannone R, Gentile V, Cortesi E, et al. (2014) Circulating tumor cells detection has independent prognostic impact in high-risk non-muscle invasive bladder cancer. Int J Cancer 135:1978-1982.

Gorges TM, Stein A, Quidde J, Hauch S, Röck K, Riethdorf S, Joosse SA, and Pantel $\mathrm{K}$ (2016) Improved detection of circulating tumor cells in metastatic colorectal cancer by the combination of the CellSearch ${ }^{\circledR}$ system and the AdnaTest $^{\circledR}$. PLoS One 11:e0155126.

Grisanti S, Antonelli A, Buglione M, Almici C, Foroni C, Sodano M, Triggiani L, Greco D, Palumbo C, Marini M, et al. (2016) Analysis of circulating tumor cells in prostate cancer patients at PSA recurrence and review of the literature. Anticancer Res 36:2975-2981.

Gupta GP and Massagué J (2006) Cancer metastasis: building a framework. Cell 127: $679-695$.

Gupta V, Jafferji I, Garza M, Melnikova VO, Hasegawa DK, Pethig R, and Davis DW (2012) ApoStream ${ }^{\mathrm{TM}}$, a new dielectrophoretic device for antibody independent isolation and recovery of viable cancer cells from blood. Biomicrofluidics 6:24133.

Han L, Chen W, and Zhao Q (2014) Prognostic value of circulating tumor cells in patients with pancreatic cancer: a meta-analysis. Tumour Biol 35:2473-2480.

Hanahan D and Weinberg RA (2011) Hallmarks of cancer: the next generation. Cell 144:646-674.

Hardingham JE, Grover P, Winter M, Hewett PJ, Price TJ, and Thierry B (2015) Detection and clinical significance of circulating tumor cells in colorectal cancer20 years of progress. Mol Med 21 (Suppl 1):S25-S31.

Hegemann M, Stenzl A, Bedke J, Chi KN, Black PC, and Todenhöfer T (2016) Liquid biopsy: ready to guide therapy in advanced prostate cancer? BJU Int 118:855-863.

Hernández-Blanquisett A, Touya D, Strasser-Weippl K, Ruiz R, St Louis J, and Goss $\mathrm{P}$ (2016) Current and emerging therapies of HER2-positive metastatic breast cancer. Breast 29:170-177.

Ilie M, Hofman V, Long-Mira E, Selva E, Vignaud JM, Padovani B, Mouroux J, Marquette CH, and Hofman P (2014) "Sentinel" circulating tumor cells allow early diagnosis of lung cancer in patients with chronic obstructive pulmonary disease PLoS One 9:e111597.

Ilie M, Long E, Butori C, Hofman V, Coelle C, Mauro V, Zahaf K, Marquette CH, Mouroux J, Paterlini-Bréchot P, et al. (2012) ALK-gene rearrangement: a comparative analysis on circulating tumour cells and tumour tissue from patients with lung adenocarcinoma. Ann Oncol 23:2907-2913.

Jang S and Atkins MB (2014) Treatment of BRAF-mutant melanoma: the role of vemurafenib and other therapies. Clin Pharmacol Ther 95:24-31.

Jiang R, Lu YT, Ho H, Li B, Chen JF, Lin M, Li F, Wu K, Wu H, Lichterman J, et al. (2015) A comparison of isolated circulating tumor cells and tissue biopsies using whole-genome sequencing in prostate cancer. Oncotarget 6:44781-44793.

Jing W, Li M, Zhang Y, Teng F, Han A, Kong L, and Zhu H (2016) PD-1/PD-L1 blockades in non-small-cell lung cancer therapy. Onco Targets Ther 9:489-502.

Johnston SR (2015) Enhancing endocrine therapy for hormone receptor-positive advanced breast cancer: cotargeting signaling pathways. J Natl Cancer Inst 107:10.

Karabacak NM, Spuhler PS, Fachin F, Lim EJ, Pai V, Ozkumur E, Martel JM, Kojic N, Smith K, Chen PI, et al. (2014) Microfluidic, marker-free isolation of circulating tumor cells from blood samples. Nat Protoc 9:694-710.

Karandish F and Mallik S (2016) Biomarkers and targeted therapy in pancreatic cancer. Biomark Cancer 8 (Suppl 1):27-35.

Khamenehfar A, Beischlag TV, Russell PJ, Ling MT, Nelson C, and Li PC (2015) Label-free isolation of a prostate cancer cell among blood cells and the single-cell measurement of drug accumulation using an integrated microfluidic chip. Biomicrofluidics 9:064104.

Klein CA (2009) Parallel progression of primary tumours and metastases. Nat Rev Cancer 9:302-312.

Krebs MG, Metcalf RL, Carter L, Brady G, Blackhall FH, and Dive C (2014) Molecular analysis of circulating tumour cells-biology and biomarkers. Nat Rev Clin Oncol 11:129-144.

Krebs MG, Sloane R, Priest L, Lancashire L, Hou JM, Greystoke A, Ward TH, Ferraldeschi R, Hughes A, Clack G, et al. (2011) Evaluation and prognostic significance of circulating tumor cells in patients with non-small-cell lung cancer. J Clin Oncol 29:1556-1563.

Kuhlmann JD, Wimberger P, Bankfalvi A, Keller T, Schöler S, Aktas B, Buderath P, Hauch S, Otterbach F, Kimmig R, et al. (2014) ERCC1-positive circulating tumor cells in the blood of ovarian cancer patients as a predictive biomarker for platinum resistance. Clin Chem 60:1282-1289.

Kuwano M, Sonoda K, Murakami Y, Watari K, and Ono M (2016) Overcoming drug resistance to receptor tyrosine kinase inhibitors: learning from lung cancer. Pharmacol Ther 161:97-110.

Larson CJ, Moreno JG, Pienta KJ, Gross S, Repollet M, O’Hara SM, Russell T, and Terstappen LW (2004) Apoptosis of circulating tumor cells in prostate cancer patients. Cytometry A 62:46-53.

Li H, Song P, Zou B, Liu M, Cui K, Zhou P, Li S, and Zhang B (2015) Circulating tumor cell analyses in patients with esophageal squamous cell carcinoma using epithelial marker-dependent and -independent approaches. Medicine (Baltimore) 94:e1565

Lianidou ES and Markou A (2011) Circulating tumor cells in breast cancer: detection systems, molecular characterization, and future challenges. Clin Chem $\mathbf{5 7}$ $1242-1255$
Lin J, Goto Y, Murata H, Sakaizawa K, Uchiyama A, Saida T, and Takata M (2011) Polyclonality of BRAF mutations in primary melanoma and the selection of mutant alleles during progression. Br J Cancer 104:464-468.

Liu HY, Qian HH, Zhang XF, Li J, Yang X, Sun B, Ma JY, Chen L, and Yin ZF (2015) Improved method increases sensitivity for circulating hepatocellular carcinoma cells. World J Gastroenterol 21:2918-2925.

Long E, Ilie M, Bence C, Butori C, Selva E, Lalvée S, Bonnetaud C, Poissonnet G, Lacour JP, Bahadoran P, et al. (2016) High expression of TRF2, SOX10, and CD10 in circulating tumor microemboli detected in metastatic melanoma patients. A potential impact for the assessment of disease aggressiveness. Cancer Med 5: $1022-1030$.

López-Riquelme N, Minguela A, Villar-Permuy F, Ciprian D, Castillejo A, ÁlvarezLópez MR, and Soto JL (2013) Imaging cytometry for counting circulating tumor cells: comparative analysis of the CellSearch vs ImageStream systems. APMIS 121:1139-1143.

Luzzi KJ, MacDonald IC, Schmidt EE, Kerkvliet N, Morris VL, Chambers AF, and Groom AC (1998) Multistep nature of metastatic inefficiency: dormancy of solitary cells after successful extravasation and limited survival of early micrometastases. Am J Pathol 153:865-873.

Mani SA, Guo W, Liao MJ, Eaton EN, Ayyanan A, Zhou AY, Brooks M, Reinhard F, Zhang CC, Shipitsin M, et al. (2008) The epithelial-mesenchymal transition generates cells with properties of stem cells. Cell 133:704-715.

Markou A, Farkona S, Schiza C, Efstathiou T, Kounelis S, Malamos N, Georgoulias V, and Lianidou E (2014) PIK3CA mutational status in circulating tumor cells can change during disease recurrence or progression in patients with breast cancer. Clin Cancer Res 20:5823-5834.

Masuda T, Hayashi N, Iguchi T, Ito S, Eguchi H, and Mimori K (2016) Clinical and biological significance of circulating tumor cells in cancer. Mol Oncol 10:408-417.

Meng S, Tripathy D, Frenkel EP, Shete S, Naftalis EZ, Huth JF, Beitsch PD, Leitch M, Hoover S, Euhus D, et al. (2004) Circulating tumor cells in patients with breast cancer dormancy. Clin Cancer Res 10:8152-8162.

Mok TS, Wu YL, Thongprasert S, Yang CH, Chu DT, Saijo N, Sunpaweravong P, Han B, Margono B, Ichinose Y, et al. (2009) Gefitinib or carboplatin-paclitaxel in pulmonary adenocarcinoma. $N$ Engl J Med 361:947-957.

Nagrath S, Jack RM, Sahai V, and Simeone DM (2016) Opportunities and challenges for pancreatic circulating tumor cells. Gastroenterology 151:412-426.

Nelson NJ (2010) Circulating tumor cells: will they be clinically useful? J Natl Cancer Inst 102:146-148.

Nichols AC, Lowes LE, Szeto CC, Basmaji J, Dhaliwal S, Chapeskie C, Todorovic B, Read N, Venkatesan V, Hammond A, et al. (2012) Detection of circulating tumor cells in advanced head and neck cancer using the CellSearch system. Head Neck 34:1440-1444.

Nieto MA (2013) Epithelial plasticity: a common theme in embryonic and cancer cells. Science 342:1234850.

Ohnaga T, Shimada Y, Takata K, Obata T, Okumura T, Nagata T, Kishi H, Muraguchi A, and Tsukada K (2016) Capture of esophageal and breast cancer cells with polymeric microfluidic devices for CTC isolation. Mol Clin Oncol 4:599-602.

Onstenk W, Sieuwerts AM, Kraan J, Van M, Nieuweboer AJ, Mathijssen RH Hamberg P, Meulenbeld HJ, De Laere B, Dirix LY, et al. (2015) Efficacy of cabazitaxel in castration-resistant prostate cancer is independent of the presence of AR-V7 in circulating tumor cells. Eur Urol 68:939-945.

O'Shannessy DJ, Davis DW, Anderes K, and Somers EB (2016) Isolation of circulating tumor cells from multiple epithelial cancers with ApoStream ${ }^{\circledR}$ for detecting (or monitoring) the expression of folate receptor alpha. Biomark Insights 11:7-18

Ozkumur E, Shah AM, Ciciliano JC, Emmink BL, Miyamoto DT, Brachtel E, Yu M, Chen PI, Morgan B, Trautwein J, et al. (2013) Inertial focusing for tumor antigendependent and -independent sorting of rare circulating tumor cells. Sci Transl Med 5:179ra47.

Pailler E, Adam J, Barthélémy A, Oulhen M, Auger N, Valent A, Borget I, Planchard D, Taylor M, André F, et al. (2013) Detection of circulating tumor cells harboring a unique ALK rearrangement in ALK-positive non-small-cell lung cancer. J Clin Oncol 31:2273-2281.

Pailler E, Auger N, Lindsay CR, Vielh P, Islas-Morris-Hernandez A, Borget I, NgoCamus M, Planchard D, Soria JC, Besse B, et al. (2015) High level of chromosomal instability in circulating tumor cells of ROS1-rearranged non-small-cell lung cancer. Ann Oncol 26:1408-1415.

Pantel K, Denève E, Nocca D, Coffy A, Vendrell JP, Maudelonde T, Riethdorf S and Alix-Panabières C (2012) Circulating epithelial cells in patients with benign colon diseases. Clin Chem 58:936-940.

Punnoose EA, Atwal S, Liu W, Raja R, Fine BM, Hughes BG, Hicks RJ, Hampton GM, Amler LC, Pirzkall A, et al. (2012) Evaluation of circulating tumor cells and circulating tumor DNA in non-small cell lung cancer: association with clinical endpoints in a phase II clinical trial of pertuzumab and erlotinib. Clin Cancer Res 18:2391-2401.

Rack B, Schindlbeck C, Jückstock J, Andergassen U, Hepp P, Zwingers T, Friedl TW Lorenz R, Tesch H, Fasching PA, et al.; SUCCESS Study Group (2014) Circulating tumor cells predict survival in early average-to-high risk breast cancer patients. $J$ Natl Cancer Inst 106:dju066.

Ramirez JM, Fehm T, Orsini M, Cayrefourcq L, Maudelonde T, Pantel K, and AlixPanabières C (2014) Prognostic relevance of viable circulating tumor cells detected by EPISPOT in metastatic breast cancer patients. Clin Chem 60:214-221.

Rao C, Bui T, Connelly M, Doyle G, Karydis I, Middleton MR, Clack G, Malone M, Coumans FA, and Terstappen LW (2011) Circulating melanoma cells and survival in metastatic melanoma. Int $J$ Oncol 38:755-760.

Reid AL, Freeman JB, Millward M, Ziman M, and Gray ES (2015) Detection of BRAF-V600E and V600K in melanoma circulating tumour cells by droplet digital PCR. Clin Biochem 48:999-1002.

Ricci-Vitiani L, Lombardi DG, Pilozzi E, Biffoni M, Todaro M, Peschle C, and De Maria R (2007) Identification and expansion of human colon-cancer-initiating cells. Nature 445:111-115. 
Riethdorf S, Fritsche H, Müller V, Rau T, Schindlbeck C, Rack B, Janni W, Coith C, Beck K, Jänicke F, et al. (2007) Detection of circulating tumor cells in peripheral blood of patients with metastatic breast cancer: a validation study of the CellSearch system. Clin Cancer Res 13:920-928.

Schneck H, Blassl C, Meier-Stiegen F, Neves RP, Janni W, Fehm T, and Neubauer H (2013) Analysing the mutational status of PIK3CA in circulating tumor cells from metastatic breast cancer patients. Mol Oncol 7:976-986.

Schulze K, Gasch C, Staufer K, Nashan B, Lohse AW, Pantel K, Riethdorf S, and Wege $H$ (2013) Presence of EpCAM-positive circulating tumor cells as biomarker for systemic disease strongly correlates to survival in patients with hepatocellular carcinoma. Int J Cancer 133:2165-2171.

Sequist LV, Nagrath S, Toner M, Haber DA, and Lynch TJ (2009) The CTC-chip: an exciting new tool to detect circulating tumor cells in lung cancer patients. $J$ Thorac Oncol 4:281-283.

Shaw JA, Guttery DS, Hills A, Fernandez-Garcia D, Page K, Rosales BM, Goddard KS, Hastings RK, Luo J, Ogle O, et al. (2017) Mutation analysis of cell-free DNA and single circulating tumor cells in metastatic breast cancer patients with high circulating tumor cell counts. Clin Cancer Res $\mathbf{2 3}$ 88-96.

Sheng W, Ogunwobi OO, Chen T, Zhang J, George TJ, Liu C, and Fan ZH (2014) Capture, release and culture of circulating tumor cells from pancreatic cancer patients using an enhanced mixing chip. Lab Chip 14:89-98.

Sholl LM, Aisner DL, Allen TC, Beasley MB, Cagle PT, Capelozzi VL, Dacic S, Hariri LP, Kerr KM, Lantuejoul S, et al. (2016) Liquid biopsy in lung cancer: a perspective from members of the Pulmonary Pathology Society. Arch Pathol Lab Med 140 $825-829$.

Smerage JB, Barlow WE, Hortobagyi GN, Winer EP, Leyland-Jones B, Srkalovic G, Tejwani S, Schott AF, O'Rourke MA, Lew DL, et al. (2014) Circulating tumor cells and response to chemotherapy in metastatic breast cancer: SWOG S0500. J Clin Oncol 32:3483-3489.

Sollier E, Go DE, Che J, Gossett DR, O'Byrne S, Weaver WM, Kummer N, Rettig M, Goldman J, Nickols N, et al. (2014) Size-selective collection of circulating tumor cells using Vortex technology. Lab Chip 14:63-77.

Sosa MS, Bragado P, and Aguirre-Ghiso JA (2014) Mechanisms of disseminated cancer cell dormancy: an awakening field. Nat Rev Cancer 14:611-622.

Starzyńska T, Dąbkowski K, Błogowski W, Zuba-Surma E, Budkowska M, Sałata D, Dołegowska B, Marlicz W, Lubikowski J, and Ratajczak MZ (2013) An intensified systemic trafficking of bone marrow-derived stem/ progenitor cells in patients with pancreatic cancer. $J$ Cell Mol Med 17: $792-799$.
Stewart JM, Shaw PA, Gedye C, Bernardini MQ, Neel BG, and Ailles LE (2011) Phenotypic heterogeneity and instability of human ovarian tumor-initiating cells. Proc Natl Acad Sci USA 108:6468-6473.

Tam WL and Weinberg RA (2013) The epigenetics of epithelial-mesenchymal plasticity in cancer. Nat Med 19:1438-1449.

Thiery JP, Acloque H, Huang RY, and Nieto MA (2009) Epithelial-mesenchymal transitions in development and disease. Cell 139:871-890.

Thompson AM, Jordan LB, Quinlan P, Anderson E, Skene A, Dewar JA, and Purdie CA; Breast Recurrence in Tissues Study Group (2010) Prospective comparison of switches in biomarker status between primary and recurrent breast cancer: the Breast Recurrence In Tissues Study (BRITS). Breast Cancer Res 12:R92.

Tulley S, Zhao Q, Dong H, Pearl ML, and Chen WT (2016) Vita-Assay ${ }^{\mathrm{TM}}$ method of enrichment and identification of circulating cancer cells/circulating tumor cells (CTCs). Methods Mol Biol 1406:107-119.

Turner NH and Di Leo A (2013) HER2 discordance between primary and metastatic breast cancer: assessing the clinical impact. Cancer Treat Rev 39:947-957.

Van Berckelaer C, Brouwers AJ, Peeters DJ, Tjalma W, Trinh XB, and van Dam PA (2016) Current and future role of circulating tumor cells in patients with epithelia ovarian cancer. Eur J Surg Oncol 42:1772-1779.

Vashist YK, Effenberger KE, Vettorazzi E, Riethdorf S, Yekebas EF, Izbicki JR, and Pantel K (2012) Disseminated tumor cells in bone marrow and the natural course of resected esophageal cancer. Ann Surg 255:1105-1112.

Winer-Jones JP, Vahidi B, Arquilevich N, Fang C, Ferguson S, Harkins D, Hill C, Klem E, Pagano PC, Peasley C, et al. (2014) Circulating tumor cells: clinically relevant molecular access based on a novel CTC flow cell. PLoS One 9:e86717.

Wong KK, Engelman JA, and Cantley LC (2010) Targeting the PI3K signaling pathway in cancer. Curr Opin Genet Dev 20:87-90.

Xenidis N, Markos V, Apostolaki S, Perraki M, Pallis A, Sfakiotaki G, PapadatosPastos D, Kalmanti L, Kafousi M, Stathopoulos E, et al. (2007) Clinical relevance of circulating CK-19 mRNA-positive cells detected during the adjuvant tamoxifen treatment in patients with early breast cancer. Ann Oncol 18:1623-1631.

Zhang L, Riethdorf S, Wu G, Wang T, Yang K, Peng G, Liu J, and Pantel K (2012) Meta-analysis of the prognostic value of circulating tumor cells in breast cancer. Clin Cancer Res 18:5701-5710.

Address correspondence to: Dr. Liwu Fu, Cancer Institute, Cancer Center, Sun Yat-sen University, Guangzhou, 510060, China. E-mail: fulw@mail.sysu. edu.cn 